\title{
ТЕРМОИЗОЛИРУЮЩИЕ ФИЛЬТРЫ В ЛИТЕЙНОМ ПРОИЗВОДСТВЕ КАК ОДНА ИЗ ГЛАВНЫХ ЭНЕРГО - РЕСУРСОСБЕРЕГАЮЩИХ ТЕХНОЛОГИЙ
}

\author{
Аксенова Д.В. \\ Сибирский государственный университет путей сообщения, \\ г. Новосибирск, Россия
}

В статье рассмотрены основные проблемь энергоэффективности $и$ ресурсосбережения в литейном производстве. Основное внимание уделяется с помощью внедрения термоизолирующих вставок и фильтров.

Ключевые слова: литейное производство, плавка, фильтры, промышленность, термоизолирующая вставка, энергопотребление, фильтрация, экономическая эффективность.

Литейное производство в России является основной закупочной базой машиностроения и в будущем сохранит свои лидирующие позиции. Литые детали составляют в среднем 50-70\% массы (до 90\% в станках) и 20\% стоимости станков. Только методы литья могут производить заготовки из черных и цветных сплавов, сложных по конфигурации и геометрии, с высоким коэффициентом использования металла $(75-98 \%)$ [1]. Отливки, как правило, несут большие нагрузки в машинах и механизмах и определяют их эксплуатационную безопасность, точность и долговечность. Российский литейный завод, который сохранился после общего кризиса 90-х годов, сейчас располагается в размеренном положении. Но большая часть компаний не имеют ресурсов для реализации радикальных проектов по реструктуризации и модернизации производства.

Увеличение продуктивности оборудования, понижение материалоемкости и энергоемкости продукции, сокращение и переработка отходов являются важными задачами на большинство производствах. В то же время сегодня металлургия и металлургия являются отраслями, которые потребляют больше всего энергии и материалов. Плавка - самый энергоемкий процесс [2]. Снижение удельного потребления энергии литейным заводом становится все более актуальной задачей каждый день в связи с постоянным ростом цен на энергоносители.

Самый дорогой источник энергии - это электричество. В то же время, благодаря постоянному совершенствованию электроплавильных устройств (индукционных и дуговых печей), доля жидкого металла, образующегося в электропечах, постоянно увеличивается. Однако термический КПД (КПД) электрического плавления сегодня все еще превышает 55-65\%: при энтальпии жидкого железа и стали приблизительно 1300 и 1500 МДж / т затраты на плавление составляют от 2 до 2,7 тысячи. МДж / т или 550 - 750 кВтч / т [5]. 
При стоимости электроэнергии в Беларуси из России от 0,1 до 0,12 долл. США за 1 кВт-ч потребление энергии на 1 тонну расплава составляет от 55 до 85 долл. США.

Тепловая энергия, теряемая в процессе плавки, не только рассеивается в атмосфере, но и расходуется на «загрязнение» окружающей среды: образование пыли, вредных веществ, высокотемпературных газов и т. д. Для проведения природоохранных мероприятий необходимо потратить эквивалентное или даже большее количество энергии (согласно первому закону термодинамики). Таким образом, экономическая эффективность внедрения методов, снижающих энергозатраты при выплавке с учетом экологических факторов, более чем удваивается.

Среди них интенсивное применение приходится на внедрение термоизолирующих вставок и фильтров, чья цель - значительно снизить затраты при производстве отливок за счет увеличения выхода отливки и снижения потерь от отходов (теплоизоляционные вкладыши для снижения веса прибыли, использование фильтров для улавливания неметаллических включений).

В контексте ужесточения стандартов качества сегодня требуются более жесткие допуски, лучшие механические свойства, более эффективные методы производства и более низкие затраты. Инженеры постоянно ищут способы удовлетворить эти потребности. Одним из способов решения этих проблем, который используется большинством ролей, является фильтрация расплава.

Фильтры имеют разные формы, размеры и состоят из разных материалов, которые специально подобраны для каждого конкретного применения [3]. Разные сплавы имеют разные температуры литья и, следовательно, вызывают разные значения теплового удара для фильтра. Некоторые фильтры не способны выдержать определенные значения теплового удара и, следовательно, разлагаются или ломаются перед заполнением формы. В результате процесс фильтрации прерывается, и также отображаются новые включения из уничтоженного фильтра.

Различные технологические методы, используемые в литниковой системе, благодаря которым можно удалять вредные загрязнения, широко распространены в использовании фильтров. Правильно установив фильтр в форму можно уменьшить общую длину каналов в литниковой системе. Уменьшение размеров системы затвора позволяет уменьшить площадь контакта металла с формовочной смесью и увеличить выход металла [5]. Кроме того, фильтрующие компоненты могут служить регуляторами расхода, помогая контролировать наполнение пресс-формы, уменьшая турбулентность и поток расплава.

Одной из проблем литейного производства являются неметаллические включения, которые всегда присутствуют в расплавленном металле и вызывают дефекты, такие как шлак и газовые оболочки, в дополнение к газовой пористости, которая снижает качество отливок и их механические свойства. Следующие процедуры устранения неполадок усложняют и значительно 
увеличивают стоимость обработки отливок. Образование неметаллических включений вызвано смешением шлака с металлом при его плавлении, утечкой в подающем лотке и утечкой в кристаллизаторе и другими факторами. Применение керамических фильтров типа ФКТ, материал изготовления которых - это модифицированный карбид титана, существенно снижает образование перечисленных дефектов [2].

Существует два основных типа керамических фильтров - прессовые керамические и пенокерамические. Характерной особенностью прессованного керамического фильтра является то, что он имеет параллельно выровненные поры одинакового размера и формы [1]. Из-за этого эти фильтры создают ламинарный характер оттока расплавов. Прессованные фильтры классифицируются по количеству пор на дюйм (ppi), расположенных на верхней поверхности фильтра, и имеющих несколько различных типов пор в геометрии. Чаще всего фильтры используются с двумя основными типами конфигурации пор - с квадратными отверстиями или отверстиями в виде сот [6].

Керамические пенные фильтры (называемые пенокерамическими фильтрами с сетчатой структурой) имеют много пор разных размеров и любых ориентаций. Эти фильтры выглядят как резиновая губка. Проходя через этот фильтр, поток расплава сталкивается с препятствием, в результате чего он меняет направление. Из-за изменения направления струи, а также из-за дополнительного трения расплав фильтруется, и скорость потока расплава уменьшается.

Не имеет ограничений ни по рабочей температуре фильтруемых сплавов, ни по их типу, что является их преимуществом по сравнению с фильтрами из традиционной керамики (кварц, корунд, оксид циркония и т. д.) [4]. Помимо уменьшения количества твердых и жидких неметаллических включений, использование фильтров позволяет снизить содержание растворенного кислорода в металле и тем самым снизить газовую пористость отформованных деталей. Эта особенность присуща только данным фильтрам.

Фильтрация - это отличный способ улучшить качество отливок и уменьшить количество отходов. Однако перед установкой фильтрации необходимо учитывать несколько моментов: при использовании фильтров в технологическом процессе усилие, связанное с общей стоимостью литья, увеличивается, и эта технология требует дополнительного технологического процесса из-за удаления фильтра из металла, возвращенного перед переплавкой. Следовательно, вся необходимость установки фильтра в производстве должна быть тщательно продумана. Но есть главное преимущество, которое охватывает все недостатки и подтверждает необходимость внедрения технологии ресурсосбережения - то, что литейная промышленность с помощью термоизолирующих вставок и фильтров может достичь высоких результатов. Правильный выбор фильтров - эффективно улавливающих включения и относительно недорогих - позволяет 
производителям добиться высокого качества и снизить затраты на плавку за счет сокращения отходов.

\section{Список литературы}

1. Аникеев В.В., Зонненберг Н.Н. Взаимосвязь наследственности и качества стальных деталей // Литейный завод - 2010. - № 6. - С.2-5.

2. Буданов Е. Н. Семь фундаментальных мифов и заблуждений о литейном производстве. «Литейный завод», № 8,9, 2009

3. Поклад В. А., Оспенникова О. Г., Рудницкий С. В., Щербина С. А. Литейный завод ФГУП «ММПП «Салют» // Фондери, 2007, № 8, с. 2-6.Трухов А.П., Литейные сплавы и плавка : учеб. для студентов высш. учеб. заведений / А.П. Трухов, А.И. Маляров. - М. : Академия, 2005. - 336с.

4. Казяев М.Д., Казяев Д.М., Вохмяков А.М. Современные руководящие указания по энергосбережению в нагревательных печах: материалы 4-го Международного конгресса «Новые направления в области теплотехнического строительства. Конструкции, технологии, материалы. Энергосбережение, экология и промышленная безопасность» (Москва. 27-28 марта 2013 г.). С. 4060.

5. Юсфин Ю.С. Основные направления ресурсосбережения при доменном производстве и его влияние на окружающую среду // Сталь. 2010. № 4. C. $12-13$. 